\title{
Elevated plasma glucagon-like peptide 1 and 2 concentrations in ileum resected short bowel patients with a preserved colon
}

\author{
P B Jeppesen, B Hartmann, J Thulesen, B S Hansen, J J Holst, S S Poulsen,
} P B Mortensen

Department of

Medicine CA-2121, Section of

Gastroenterology,

Rigshospitalet, University of

Copenhagen, Denmark

P B Jeppesen

B S Hansen

P B Mortensen

Department of

Medical Anatomy,

Panum Institute,

University of

Copenhagen, Denmark

J Thulesen

S S Poulsen

Department of Physiology, Panum

Institute, University of

Copenhagen, Denmark

B Hartmann

J J Holst

Correspondence to:

Dr P B Jeppesen,

Department of Medicine

CA-2121, Section of

Gastroenterology,

Rigshospitalet, Blegdamsve

9, DK-2100 Copenhagen,

Denmark. Email:

Bekker@dadlnet.dk

Accepted for publication 4 April 2000

\begin{abstract}
Abstra ct
Background-The glucagon-like peptides (GLP) 1 and 2 are secreted postprandially from $L$ cells located mainly in the ileum. Both hormones prolong intestinal transit and GLP-2 is intestinotrophic in rodents. Patients with a jejunostomy have poor adaptation, rapid gastric and intestinal transit, and impaired postprandial GLP-2 secretion. Ileum resected short bowel patients with a preserved colon show evidence of functional adaptation and have normal gastric emptying.

Aim-To investigate if GLP-1 and GLP-2 contribute to the positive effects of a preserved colon in short bowel patients by measuring circulating levels of GLP-1 and GLP-2 in seven ileum resected short bowel patients with a preserved colon and seven age and sex matched controls.

Methods-GLP-1 and GLP-2 immunoreactivity was measured by specific radioimmunoassays in plasma collected at fasting and at regular intervals $180 \mathrm{~min}$ utes after a test meal.

Results-Median (25-75\%) fasting GLP-2 values were $72(69-105) \mathrm{pmol} / 1$ versus 23 (19-27) $\mathrm{pmol} / 1 \mathrm{l}(\mathrm{p}=0.001)$ and meal stimulated area under the curve was 21078 (14 811-26 610) $\mathrm{min} \times \mathrm{pmol} / 1$ versus 11150 (7151-12 801) $\min \times \mathbf{p m o l} / 1(p=0.01)$ in short bowel patients with a preserved colon compared with control subjects. Fasting GLP-1 values were 10 (6-12) pmol/1 versus 5 (3-5) pmol/1 $(p=0.01)$ and meal stimulated area under the curve was 3418 (29666850) $\min \times \mathrm{pmol} / 1$ versus 2478 (1929-3199) $\min \times \mathbf{p m o l} / 1(\mathrm{p}=0.04)$, respectively.

Conclusion-Ileum resected short bowel patients with a preserved colon had elevated fasting plasma concentrations of GLP-1 and GLP-2 and significantly larger meal stimulated areas under the curve compared with age and sex matched controls. Elevated GLP-1 and GLP-2 concentrations may contribute to the positive effects of a preserved colon on intestinal motility and functional adaptation in ileum resected short bowel patients. (Gut 2000;47:370-376)
\end{abstract}

Keywords: short bowel syndrome; colon; glucagon-like peptides; intestinal adaptation; intestinal transit

The presence of a distal ileal and colonic peptide with glucagon-like immunoreactivity, termed enteroglucagon, was originally demonstrated when antisera raised against the pancreatic hormone glucagon were found to react with intestinal endocrine L cells. ${ }^{1}$ However, the molecular structure of enteroglucagon was not known and serum concentrations were derived by subtracting pancreatic glucagon concentrations from total glucagon-like immunoreactivity. Later it was found that tumours producing peptides with glucagon-like immunoreactivity were associated with intestinal mucosal hyperplasia, and the search for specific peptides related to intestinal adaptation after resection has been intensive. ${ }^{23}$ Recently published data indicate that glucagon-like peptide 2 (GLP-2) is a highly specific intestinotrophic mediator in rodents ${ }^{4-6}$ although glicentin and oxyntomodulin are the peptides responsible for glucagonlike immunoreactivity initially described. ${ }^{78}$ Glicentin, oxyntomodulin, GLP-2, and glucagon-like peptide 1 (GLP-1) are secreted via post-transitional processing of proglucagon from $L$ cells of the distal small intestine ${ }^{9}$ and possibly in the colon, ${ }^{10}{ }^{11}$ whereas glucagon, glicentin related pancreatic peptide, and the major proglucagon fragment are produced by differential processing of proglucagon in the pancreatic A cells.

It has been speculated that L cells, through secretion of proglucagon derived peptides, may serve as sensors in the distal intestine providing feedback to the upper intestine to optimise nutrient and fluid absorption. Thus increasing loads of nutrients or fluid into the ileum and colon may stimulate secretion of glicentin, oxyntomodulin, GLP-1, and GLP-2. Whereas the biological activity of glicentin and oxyntomodulin remain controversial, ${ }^{12}$ GLP-1 is a insulinotrophic hormone $\mathrm{e}^{13}$ and also inhibits gastric secretion and motility by inhibiting central parasympathetic outflow. ${ }^{15}$ In addition to mediating increased jejunal absorption through induction of jejunal epithelial proliferation, GLP-2 has been shown to decrease gastric emptying, ${ }^{16}$ increase intestinal transit time, and inhibit sham feeding induced gastric acid secretion. ${ }^{17}$ Administration of a potent protease resistant analogue of GLP-2 augmented the adaptive response to massive intestinal resection in rodents, ${ }^{18}$ and postresectional intestinal growth correlates with circulating GLP-2 levels. ${ }^{19}$ Therefore, GLP-1 and GLP-2 may prove to be important factors

Abbreviations used in this paper: GLP,

glucagon-like peptide; BMR, basal metabolic rate. 
Table 1 Comparison of ileum resected short bowel patients with a preserved colon and sex and age matched healthy control subjects

\begin{tabular}{lccl}
\hline & Intestinal failure $(n=7)$ & Controls $(n=7)$ & ${ }^{*} p$ Value \\
\hline Sex $(\mathrm{F} / \mathrm{M})$ & $5 / 2$ & $5 / 2$ & - \\
Age $(\mathrm{y})$ & $56.7(43.0-60.4 ; 38.8-75.8)$ & $49.8(44.9-52.7 ; 36.4-66.4)$ & 0.62 \\
Weight $(\mathrm{kg})$ & $58.0(51.4-67.7 ; 47.2-71.7)$ & $62.0(60.3-70.0 ; 60.0-80.0)$ & 0.38 \\
Height $(\mathrm{m})$ & $171(158-176 ; 153-181)$ & $172(168-180 ; 158-182)$ & 0.46 \\
BMI $\left(\mathrm{kg} / \mathrm{m}^{2}\right)$ & $20.4(19.6-23.1 ; 18.1-23.2)$ & $21.5(20.9-22.0 ; 20.3-24.2)$ & 0.54 \\
BMR $(\mathrm{MJ} /$ day $)$ & $5.6(5.3-6.7 ; 5.2-7.1)$ & $5.7(5.6-6.8 ; 5.4-7.6)$ & 0.46
\end{tabular}

Results are median (25-75\%; range).

$\mathrm{BMR}$, basal metabolic rate; BMI, body mass index.

${ }^{\star}$ Mann-Whitney rank sum test.

in the adaptive processes in the remnant intestine following intestinal resection.

In patients with a jejunostomy suffering from intestinal failure, circulating levels of GLP-2, which normally increase following nutrient ingestion, have been demonstrated to be low. ${ }^{20}$ This is in accordance with the modest increases (at most $20-30 \%$ ) in the markers of the adaptive response in the jejunal remnant after ileectomy. ${ }^{21}$ In general, patients with less than $100-150 \mathrm{~cm}$ of jejunum need parenteral support whereas as little as $50 \mathrm{~cm}$ may be sufficient to avoid parenteral support if the colon is intact. ${ }^{22-24}$ Thus preservation of the colon seems to be beneficial in the adaptive process following intestinal resection. ${ }^{25}$ This phenomenon has been explained by colonic fermentation, mainly of carbohydrates, production of short chain fatty acids, and the digestive function of the colon as small bowel failure proceeds. ${ }^{26}$ The fact that patients with a preserved colon compared with those without a colon have a decrease in fat excretion in extreme situations when less than $50 \mathrm{~cm}$ of the small bowel is functioning, ${ }^{26}$ combined with the fact that long chain fatty acids are not absorbed in the human colon, indicate the existence of an unknown effect of a preserved colon on small bowel absorption. To investigate if GLP-1 and GLP-2 contribute to the positive effects of a preserved colon on small bowel adaptation and function in patients with severe malabsorption, we investigated circulating levels of GLP-1 and GLP-2, as well as total glucagon immunoreactivity (mainly enteroglucagon), in the fasting state and after ingestion of a meal in seven ileum resected short bowel patients with preserved colonic function and seven age and sex matched controls.

\section{Material and methods}

\section{PATIENTS}

Seven short bowel patients $(<140 \mathrm{~cm}$ remnant small bowel) and seven healthy age and sex matched controls were recruited. Four of the patients had a jejunoileo-colonic anastomosis with an intact ileocaecal valve but none had more than $10 \mathrm{~cm}$ of ileum preserved. The last three patients had a jejuno-colonic anastomosis. All patients had more than $57 \%$ of their colon intact, ${ }^{27}$ and all except one patient with a sigmoidostomy had preserved rectoanal function. Characteristics of the patients and control subjects are compared in table 1 . Four females and three males were studied in both groups. There were no differences in age between groups in accordance with pair selection of the control subjects, and no differences in weight, height, body mass index, or basic metabolic rate (BMR), calculated using the HarrisBenedict equations. ${ }^{28}$

In patients, the causes that led to short bowel syndrome were mesenteric infarction $(n=3)$, Crohn's disease $(n=2)$, midgut volvulus $(n=1)$, and intestinal bypass operation due to familial hypercholesterolaemia $(n=1)$. None of the patients with Crohn's disease had clinical or biochemical signs of active disease, and none of the patients or control subjects had undergone stomach or duodenal surgery. The length of the remnant small intestine from the ligament of Treitz had been measured intraoperatively in all patients. In patients, the length of the remnant small bowel averaged $89 \mathrm{~cm}$ (range 45-140) and the remnant colon $84 \%$ (range $57-100 \%$ ). All patients were considered to be in a stable phase. The last small bowel resection had been performed 10.3 years before the study (range 0.8-18.1). The two patients with Crohn's disease received parenteral support and had done so for nine and seven years, respectively. One of these patients received only saline whereas the other also received parenteral nutrition.

All patients were closely monitored and had continuity of care as participants in the programme for patients with intestinal insufficiency and failure at Rigshospitalet, Copenhagen. ${ }^{29}$ As part of the programme, intestinal absorption had been measured within two years before entering the study. ${ }^{30}$ During a 48 hour balance period spontaneous energy and wet weight intake, faecal energy, and weight loss were measured. Analysis was performed on homogenised and freeze dried aliquots of dietary and faecal samples. Dietary and faecal energy was determined by bomb calorimetry in an IKA adiabatic calorimeter, model C 4000 A (IKA-Analysentechnik, Heitersheim, Germany), whereas carbohydrates, fat, and protein were determined as previously described. ${ }^{31}{ }^{32}$ The results of the balance studies are given in table 2 and compared with the results of the balance studies in seven short bowel patients with a jejunostomy previously described. ${ }^{20}$ The need for parenteral supplements in the two patients with Crohn's disease was evidenced by an intestinal wet weight absorption of only 0.8 $\mathrm{kg}$ /day in both patients, with energy absorption providing $72 \%$ and $137 \%$ of BMR.

\section{STUDY PROTOCOL}

Patients and healthy controls were admitted for a test meal after an overnight fast prior to admission. Before the test meal, height and fasting body weight of the patients and controls were measured. All were given a large but standard breakfast consisting of rye bread, toast, butter, cheese, jam, yoghurt, banana, and orange juice (total weight $755 \mathrm{~g}$ ), with an energy content of $3.92 \mathrm{MJ}(936 \mathrm{kcal})$ and a protein:carbohydrate:fat energy ratio of 10\%:52\%:37\% evaluated from food tables. ${ }^{33}$ Dietary fibre was approximately $8 \mathrm{~g}$. Peripheral venous blood was collected 15 minutes before and $10,20,30,45,60,120$, and 180 minutes 
Table 2 Patient characteristics

\begin{tabular}{lll}
\hline & \multicolumn{2}{l}{ Short bowel patients } \\
\cline { 2 - 3 } & Preserved colon $(n=7)$ & fejunostomy $(n=7)^{20}$ \\
\hline Diet energy intake (MJ/day) & $9.3(9.1-14.6)$ & $10.4(7.4-10.7)$ \\
Energy absorption (MJ/day) & $7.2(5.8-8.3)$ & $4.7(2.2-5.2)^{\star}$ \\
Fat intake $(\mathrm{MJ} /$ day) & $2.5(2.1-3.5)$ & $2.6(1.7-3.0)$ \\
Fat absorption (MJ/day) & $0.8(0.4-1.7)$ & $0.6(0.1-0.7)^{\star \star}$ \\
Protein intake $(\mathrm{MJ} /$ day) & $2.0(1.9-3.1)$ & $2.2(1.6-2.5)$ \\
Protein absorption (MJ/day) $\dagger$ & $1.2(0.8-1.7)$ & $0.5(0.2-0.7)$ \\
Carbohydrate intake $(\mathrm{MJ} /$ day) & $4.9(3.9-7.2)$ & $3.6(3.2-4.3)$ \\
Carbohydrate absorption $(\mathrm{MJ} /$ day) & $4.4(3.6-6.4)$ & $1.7(1.1-2.9)^{\star \star \star}$ \\
Wet weight intake (kg/day) & $3.6(2.9-5.3)$ & $4.3(2.6-4.7)$ \\
Wet weight absorption (kg/day) & $2.7(1.3-3.3)$ & $0.4(-1.9-1.7)^{\star}$ \\
\hline
\end{tabular}

Results are median (25-75\%).

†Stool nitrogen $(\mathrm{g})$ was converted to stool protein by multiplying by 6.25 . Energy derived from stool protein was determined by multiplying the gram quantity of stool protein by $23.6 \mathrm{~kJ} / \mathrm{g}$. ${ }^{\star} \mathrm{p}<0.05 ;{ }^{\star \star} \mathrm{p}=0.053 ;{ }^{\star \star \star} \mathrm{p}<0.001$

after the start of the meal, which was completed in 15 minutes.

None of the control subjects was receiving any medications on a regular basis prior to the study. The two patients receiving parenteral support received their usual supplements and medication the night before admission. All other patients took their usual medication prior to admission.

HORMONE ANALYSIS

Blood samples were collected in ice chilled $10 \mathrm{ml}$ tubes containing ethylenediaminetetraacetic acid (EDTA) and a specific dipeptidyl peptidase IV inhibitor, valine pyrrolidide (a generous gift from R D Carr and A Kanstrup, Novo Nordisk A/S, Bagsværd, Denmark), in final concentrations of $3.7 \mathrm{mmol} / 1$ and $0.01 \mathrm{mmol} / 1$, respectively. The tubes were immediately shaken, subsequently kept on ice, and centrifuged at $4^{\circ} \mathrm{C}$ for 10 minutes within 45 minutes of collection. Plasma was separated and stored at $-20^{\circ} \mathrm{C}$ until analysed.

For GLP-2 measurements, plasma aliquots were extracted by ethanol precipitation (75\% $\mathrm{v} / \mathrm{v}$, final concentration). We used a specific $\mathrm{NH}_{2}$ terminal radioimmunoassay as previously described $^{16}$ : antiserum 92160 was used in a final dilution of 1:35000, the standard was recombinant human GLP-2, and the tracer was synthetic bovine GLP-2 with a Thr $\rightarrow$ Tyr substitution in position $12,{ }^{125}$ I labelled using the standard stoichiometric chloramine $\mathrm{T}$ method. Free and bound moieties were separated with plasma coated charcoal. The experimental detection limit was $5 \mathrm{pmol} / \mathrm{l}$, and the intraassay coefficient of variation was $5 \%$ at a concentration of $40 \mathrm{pmol} / \mathrm{l}$. Because of interassay variation of $10-20 \%$, all samples were analysed in one batch, blinded to their source. ${ }^{34}$ GLP-1 was measured as previously described ${ }^{35}$ using antiserum 89390 measuring the amidated $\mathrm{COOH}$ terminus of GLP-1 $\left(7-36 \mathrm{NH}_{2}\right)$, standards, and ${ }^{125} \mathrm{I}$ labelled tracer GLP-1(7$\left.36 \mathrm{NH}_{2}\right)$. An insignificant amount of GLP$1\left(1-36 \mathrm{NH}_{2}\right)$ is secreted from the pancreas which is also measured by the assay. However, this contribution is of negligible importance compared with intestinal secretion. ${ }^{36}$ For measurements of GLP-1, plasma aliquots were extracted by ethanol precipitation $(70 \% \mathrm{v} / \mathrm{v}$, final concentration). Total glucagon immunoreactivity was measured using a side viewing antiserum 4304 which cross reacts with equal strength with all peptides that contain the glucagon sequence-that is, pancreatic glucagon and enteroglucagon (glicentin and oxyntomodulin). Plasma aliquots were extracted by ethanol precipitation $(61 \% \mathrm{v} / \mathrm{v}$, final concentration). We used ${ }^{125} \mathrm{I}$ labelled glucagon as tracer and highly purified porcine glucagon as a standard as previously described. ${ }^{737}$

ETHICS

Procedures followed were in accordance with the ethical standards of the Helsinki Declaration of 1975, as revised in 1983. The protocol was approved by the Ethics Committee for Medical Research in Copenhagen, Denmark. Patients and controls gave informed consent.

\section{STATISTICAL ANALYSIS}

Results are expressed as median (25\% and $75 \%$ percentiles). GLP-1, GLP-2, and total glucagon immunoreactivity responses, increments, and areas under the curves in short bowel patients were compared with results in control subjects using a non-parametric MannWhitney rank sum test at all sample times. A Friedman repeated measures analysis of variance on ranks was used to detect differences in the responses within the two groups at the different sampling times, and a multiple pairwise procedure was used as the post hoc test to compare responses at all sampling times in relation to baseline values ( -15 minutes). The SigmaStat for Windows Version 2.0 (Copyright 1992-1995, Jandel Corporation, Erkrath, Germany) was used for statistical calculations. A value of $\mathrm{p}<0.05$ was considered significant.

\section{Results}

Fasting plasma concentrations of GLP-2, GLP-1, and total glucagon immunoreactivity (pancreatic glucagon, glicentin, and oxyntomodulin) and changes in response to breakfast are given in fig 1 .

GLP-2

In control subjects, median GLP-2 concentrations increased from a baseline value of $23 \mathrm{pmol} / 1$ to a peak concentration of $60 \mathrm{pmol} / 1$ at 60 minutes. A significant postprandial increase in plasma GLP-2 concentration was demonstrated at all times $(\mathrm{p}<0.05)$ compared with baseline values, except at 180 minutes where GLP-2 concentrations returned to baseline. In short bowel patients with a preserved colon, the median baseline GLP-2 value (72 pmol/1) was more than threefold higher compared with control subjects $(p=0.001)$. Thus six of seven patients had baseline values of GLP-2 above $54 \mathrm{pmol} / \mathrm{l}$, which was the upper limit of baseline values in the control subjects. The three short bowel patients with a jejunocolonic anastomosis had baseline GLP-2 concentrations exceeding $68 \mathrm{pmol} / 1$ and thus did not differ from patients who retained $10 \mathrm{~cm}$ of ileum at most and a preserved ileocaecal valve. Plasma GLP-2 concentrations remained high throughout the study in patients and were significantly higher than control subjects at 10 , 120 , and 180 minutes (all p<0.01). Although a 

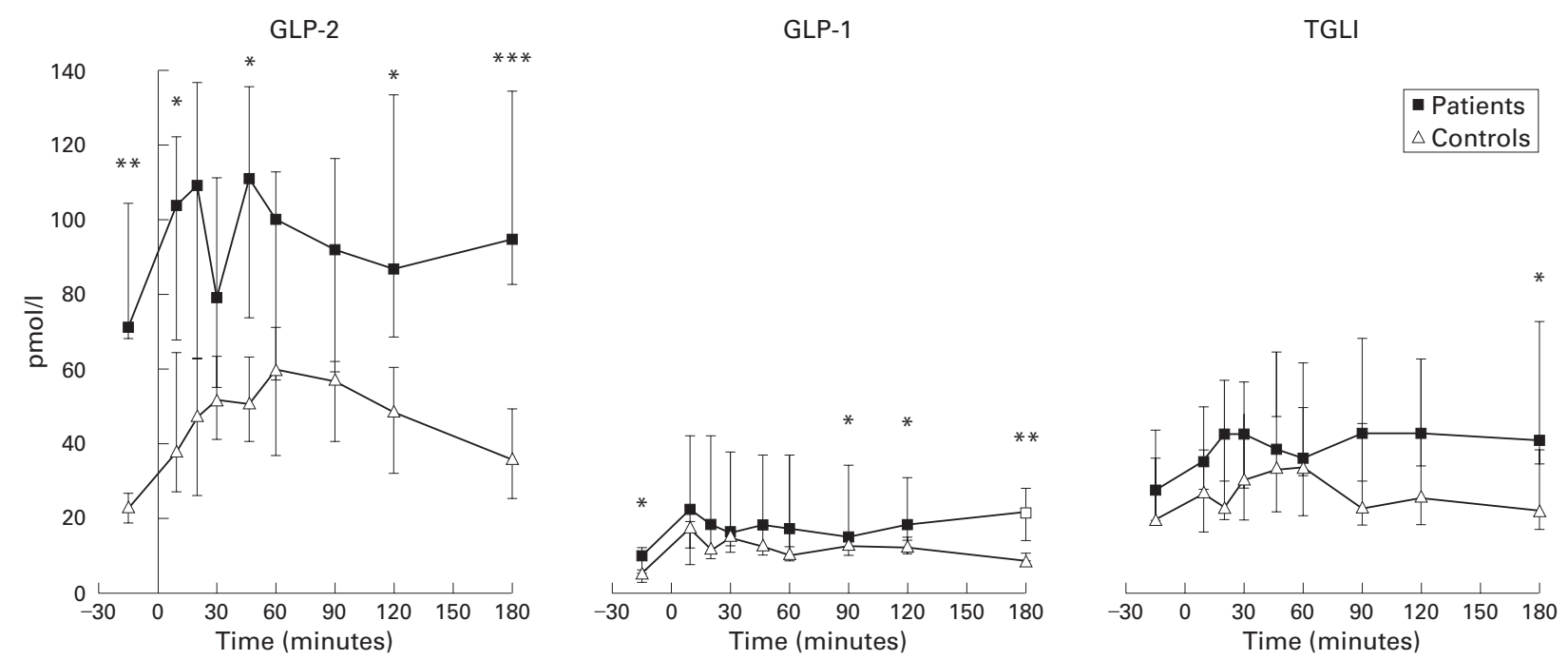

Figure 1 Meal stimulated glucagon-like peptides 1 and 2 (GLP-2, GLP-1), and total glucagon-like immunoreactivity (TGLI) responses (pmol/l) in patients and controls. Results are median $(25-75 \%) .{ }^{\star} p<0.05,{ }^{\star *} p<0.01,{ }^{\star \star}{ }^{*} p<0.001$, Mann-Whitney rank sum test, patients versus controls.

postprandial meal stimulated increase in median GLP-2 responses was seen in short bowel patients, this did not differ significantly from baseline values $(p=0.77)$.

The calculated area under the curve was significantly larger after the test meal in the short bowel patients with a preserved colon compared with control subjects (median $(25 \%-75 \%)$ ): 21078 (14 $811-26 \quad 610) \quad \mathrm{min} \times \mathrm{pmol} / 1$ versus $11150(7151-12$ 801) $\min \times \mathrm{pmol} / 1(\mathrm{p}=0.01)$. When the differences in baseline values were adjusted to compare meal stimulated GLP-2 changes in patients and control subjects, the increase in GLP-2 was defined as the actual GLP-2 value minus baseline values. There was no significant difference in the area under the increment curves in patients and controls $(-473$ $(-3221$ to 5050$)$ min $\times \mathrm{pmol} / 1$ versus 4198 (3603-6379) $\min \times \mathrm{pmol} / \mathrm{l}, \mathrm{p}=0.17)$.

GLP-1

In control subjects, median GLP-1 responses increased from a baseline value of $5 \mathrm{pmol} / 1$ to a peak concentration of $17 \mathrm{pmol} / 1$ at 10 minutes. A significant postprandial increase in plasma GLP-1 concentrations was demonstrated at all times $(p<0.05)$ compared with baseline values. In short bowel patients with a preserved colon, the median baseline GLP-1 value was twofold higher compared with control subjects $(\mathrm{p}=0.01)$. Plasma GLP-1 concentrations remained high throughout the study in patients and were significantly higher than those in control subjects at 90, 120, and 180 minutes (all $\mathrm{p}<0.05)$. Although a postprandial meal stimulated increase in median GLP-1 responses was seen in short bowel patients, this did not differ significantly from baseline values $(\mathrm{p}=0.26)$.

The calculated area under the curve was significantly larger after the test meal in short bowel patients with a preserved colon compared with control subjects (median (25\%$75 \%)$ ): 3418 (2966-6850) $\mathrm{min} \times \mathrm{pmol} / 1$ versus 2478 (1929-3199) $\min \times \mathrm{pmol} / 1 \quad(\mathrm{p}=0.04)$. There was no significant difference in the area under the increment curves in patients and controls (2128 (598-4969) $\mathrm{min} \times \mathrm{pmol} / 1$ versus 1558 (1388-1872) $\min \times \mathrm{pmol} / 1$, respectively $(\mathrm{p}=0.62))$.

TOTAL GLUCAGON IMMUNOREACTIVITY (PANCREATIC GLUCAGON, GLICENTIN, AND OXYNTOMODULIN)

In control subjects, median concentrations of total glucagon immunoreactivity increased from a baseline value of $19 \mathrm{pmol} / 1$ to a peak concentration of $32 \mathrm{pmol} / 1$ at 45 minutes. A significant postprandial increase in plasma concentrations of total glucagon immunoreactivity was demonstrated at 45 and 60 minutes $(p<0.05)$ compared with baseline values. No significant differences in median baseline concentrations of total glucagon immunoreactivity were demonstrated between controls and short bowel patients with a preserved colon. Plasma concentrations of total glucagon immunoreactivity remained constant throughout the study in the patients and were significantly higher than control subjects only at 180 minutes $(p=0.04)$. Although a postprandial meal stimulated increase in median concentrations of total glucagon immunoreactivity was seen in short bowel patients, this did not differ significantly from baseline values $(\mathrm{p}=0.08)$.

The calculated area under the curve did not differ significantly after the test meal in short bowel patients with a preserved colon compared with controls (median $(25 \%-75 \%)$ ): 8693 (6140-12515) $\mathrm{min} \times \mathrm{pmol} / \mathrm{l}$ versus 5403 (4260-8825) $\min \times \mathrm{pmol} / 1 \quad(\mathrm{p}=0.10))$. There was no significant difference in the area under the increment curves in patients and controls (3250 (260-7006) $\min \times \mathrm{pmol} / 1$ versus 913 (83-1813) $\min \times \mathrm{pmol} / \mathrm{l})(\mathrm{p}=0.21)$.

No significant correlation was observed between the amount or concentration of faecal long chain fatty acids and baseline values of GLP-1, GLP-2, or total glucagon immunoreactivity.

\section{Discussion}

This is the first study describing elevated plasma concentrations of GLP-1 and GLP-2 
following meal stimulation in ileum resected short bowel patients with a preserved colon. In a recently published study, we demonstrated normal baseline concentrations but a severely impaired meal stimulated GLP-2 response in ileum resected short bowel patients with a jejunostomy using the same study design. ${ }^{20}$ The remnant jejunal length in these patients (mean (SD)) was 111 (53) $\mathrm{cm}$ which did not differ significantly from the remnant small bowel in the ileum resected short bowel patients with a preserved colon in this study $(89(42) \mathrm{cm})$ $(p=0.39)$. In contrast with the seven patients with a jejunostomy described previously, four of the seven short bowel patients with a preserved colon in this study also retained $10 \mathrm{~cm}$ of ileum at most. However, the remaining three patients with a jejuno-colonic anastomosis had equivalently high baseline GLP-2 concentrations and therefore it seems unlikely that the increase is related solely to the presence of a short $(<10 \mathrm{~cm})$ ileal segment in the four patients. Although GLP-1 and GLP-2 under normal conditions are believed to be produced mainly by the enteroendocrine L cells of the distal small intestine, ${ }^{9}$ it seems that $\mathrm{L}$ cells located in the human colon are capable of significant GLP-1 and GLP-2 secretion when all or large parts of the ileum are surgically removed.

Intestinal absorption was measured before entering the study in the short bowel patients with a preserved colon and compared with patients with jejunostomies previously described (table 2). Absorption of long chain fat tended to be higher in patients with a preserved colon compared with those with a jejunostomy (0.8 $0.6 \mathrm{MJ} /$ day; $\mathrm{p}=0.053)$ (table 2) although no significant differences in remnant small bowel length were observed between the two groups. Large amounts of long chain fat, carbohydrates, and protein were malabsorbed from the jejunum into the colon in the ileum resected small bowel patients in this study (table 2), and a significant fraction of these macronutrients pass through the colon unabsorbed and may stimulate $\mathrm{L}$ cells in the colon. The nature of the $\mathrm{L}$ cell stimulating agent in normal humans was investigated by Xiao and colleagues. ${ }^{38}$ They demonstrated increased GLP-2 levels after carbohydrate and fat meals in normal subjects whereas a protein meal had no effect. This is in keeping with the direct stimulatory effects of both glucose and long chain monounsaturated fatty acids described in the rat L cell. ${ }^{39}{ }^{40}$ In normal humans receiving a mixed meal, the GLP-2 response and duration depend on meal size. ${ }^{20}$ It is possible that sufficient digestion and absorption of macronutrients in the duodenum and jejunum prevents stimulation of the ileal and colonic L cells and thereby GLP secretion. In conditions with a high nutrient load or impaired jejunal or ileal function, macronutrients may pass more distally in the gastrointestinal tract before being absorbed, thereby triggering GLP secretion from ileal or colonic L cells. However, because plasma levels of GLPs rise rapidly after nutrient ingestion, before nutrients reach the ileum a more complex neuroendocrine loop involving the enteric nervous system, afferent and efferent vagus nerves, as well as duodenal hormones may be involved..$^{39}$

Elevated baseline GLP concentrations observed in the ileum resected short bowel patients in this study may be explained by the presence of fat or carbohydrate in the colon even after overnight fasting. Long chain fat is not absorbed in the colon ${ }^{32}$ but no significant correlation was observed between the amount or concentration of faecal long chain fatty acids and baseline values of GLP-1, GLP-2, or total glucagon immunoreactivity in this study. However, measurements of intestinal absorption were performed prior to admission on their habitual diet. Most of the carbohydrates and protein malabsorbed in the small bowel is fermented into short chain fatty acids which are readily absorbed in the colon. ${ }^{26}{ }^{32} 4243$ Short chain triglycerides or fatty acids have been shown to stimulate intestinal mucosal growth when administered both perorally, ${ }^{44}$ intracolonically, ${ }^{45} 46$ and intravenously. ${ }^{47}$ The mechanism of this growth during peroral administration has previously been related to provision of preferred oxidative fuels to the intestinal mucosa: butyrate directly to the colon, ${ }^{45}$ and via hepatic metabolism of short chain fatty acids, glutamine to the small bowel. ${ }^{48}$ However, Sakata demonstrated that short chain fatty acids given into the hindgut lumen indirectly stimulated epithelial cell proliferation of an isolated and denervated jejunal segment of the rat. ${ }^{49} \mathrm{He}$ suggested that the trophic effects in the small intestine may be hormonally mediated through release of gastrointestinal regulatory peptides. Furthermore, short chain fatty acid supplemented parenteral nutrition has been demonstrated to increase proglucagon abundance, ${ }^{50}$ and this abundance together with increased concentrations of proglucagon derived peptides have been demonstrated to be strongly correlated with cellular proliferation during intestinal adaptation. ${ }^{51-54}$ Thus although long chain fatty acids and carbohydrates are possible stimulants of GLP secretion, it is intriguing to speculate on a relationship between ongoing colonic fermentation, production and absorption of short chain fatty acids, and elevated levels of GLPs. In the present study, the significance of colonic fermentation, and production and absorption of short chain fatty acids is illustrated by increased absorption of carbohydrates (approximately $2.5 \mathrm{MJ} /$ day) in the ileum resected short bowel patients compared with the group of patients with jejunostomies (table 2).

Elevated baseline levels of GLP-2 may have contributed to the trend observed regarding the increase in small bowel absorption of long chain fatty acids in short bowel patients with a preserved colon compared with the short bowel patients with a jejunostomy (table 2). With the pronounced malabsorption of the test meal into the colon, a larger meal stimulated GLP-2 increase is expected compared with controls, but in contrast, a diminished response could also have been anticipated in a GLP-2 secreting system already "exhausted" by near maximal secretion. We found almost identical meal 
stimulated GLP-2 responsiveness in short bowel patients compared with controls, but the reason for this awaits further investigation.

The importance of luminal nutrients and particularly non-digestible components of the diet on intestinal growth and adaptation has previously been emphasised. ${ }^{55-59}$ However, several gastrointestinal regulatory peptides, including gastrin, peptide YY, enteroglucagon, neurotensin, ${ }^{6061}$ epidermal growth factor, and others, have been considered as potential candidates in the regulation of intestinal mucosal growth and adaptation. The relative efficacy and importance of the various specific growth factors in the control of small bowel proliferation remains to be determined. In contrast with the majority of these growth factors, the growth promoting properties of GLP-2 appear to be highly tissue specific, with proliferation detected only in the intestine.

Comparing short bowel patients with and without a preserved colon, there is a striking difference in gastric emptying. ${ }^{62}$ Rapid early gastric emptying of liquid is described in patients with a jejunostomy which contrasts with findings in patients with a preserved colon in whom gastric emptying is normal. Thus in the absence of much of the small intestine, the colon has been shown to act as a brake to gastric emptying. The mechanism could be neural or humoral, and so far peptide YY, produced by the terminal ileum and colon, ${ }^{63}$ has been suggested to be responsible for the colonic brake mechanism. ${ }^{64}$ Whereas peptide YY and GLP-1 may play a part in the regulation of intestinal motility and transit that occurs in patients with a retained colon, the morphological adaptive changes are related only to GLP-2 ${ }^{65}$ Elevated GLP-1 and GLP-2 concentrations demonstrated in this study support the recognition of the involvement of these two hormones in the regulation of intestinal transit.

In conclusion, elevated plasma concentrations of GLP-1 and GLP-2, evidenced by the larger areas under the curves following meal stimulation in ileum resected short bowel patients with a preserved colon compared with sex and age matched controls, suggest that these hormones may contribute to the positive effects of a preserved colon in short bowel syndrome. It is important to emphasise that the patients in this study were nutritionally replete, and the conclusions therefore may not be applicable to the more critical times shortly after the onset of short bowel syndrome when the rate of adaptation is greatest. However, in these patients a correlation between the time from last surgery and the area under the curve for GLP-1 and GLP-2, as evidence of changes with time, could not be demonstrated. The role of GLP-2 in promoting intestinal growth makes it a potential useful treatment for patients with a short or damaged bowel. Ongoing clinical trials are focusing on the effects of subcutaneous GLP-2 injections on jejunal morphological and functional adaptation in short bowel patients with a jejunostomy. The actions of GLP-1 and GLP-2 may offer new perspectives in the treatment of short bowel patients with ileal and colonic resections, and these patients constitute the majority of the increasing number of patients with intestinal failure receiving home parenteral nutrition. ${ }^{29} 6667$

The technical assistance of Jette Christiansen and Dorte Christensen is greatly appreciated.

1 Unger RH, Eisentraut AM, Sims K, et al. Site of origin of lucagon in dogs and humans. South Soc Clin Res 1961;9:53.

2 Gleeson MH, Bloom SR, Polak JM, et al. Endocrine tumour in kidney affecting small bowel structure, motility, and function. Gut 1971;12:773-82.

3 Stevens FM, Flanagan RW, O'Gorman D, et al. Glucagonoma syndrome demonstrating giant duodenal villi. Gut 1984;25:784-91.

4 Drucker DJ, Erlich P, Asa SL, et al. Induction of intestinal epithelial proliferation by glucagon-like peptide 2. Proc Natl Acad Sci USA 1996;93:7911-16.

5 Tsai CH, Hill M, Drucker DJ. Biological determinants of intestinotrophic properties of GLP-2 in vivo. Am $\mathcal{F}$ Physiol 1997;272:G662-8.

6 Tsai CH, Hill M, Asa SL, et al. Intestinal growth-promoting properties of glucagon-like peptide-2 in mice. Am $\mathcal{F}$ Physiol -77-84.

7 Holst JJ. Evidence that glicentin contains the entire sequence of glucagon. Biochem f 1980;187:337-43.

8 Thim L, Moody AJ. The primary structure of porcine glicentin (proglucagon). Regul Pept 1981;2:139-50.

9 Orskov C, Holst JJ, Knuhtsen S, et al. Glucagon-like peptides GLP-1 and GLP-2, predicted products of the glucagon gene, are secreted separately from pig small intestine but not pancreas. Endocrinology 1986;119:1467-75.

10 Varndell IM, Bishop AE, Sikri KL, et al. Localization of glucagon-like peptide (GLP) immunoreactants in human gut and pancreas using light and electron microscopic immunocytochemistry. F Histochem Cytochem 1985;33: $1080-6$.

11 Larsson LI, Holst J, Hakanson R, et al. Distribution and properties of glucagon immunoreactivity in the digestive tract of various mammals: an immunohistochemical and immunochemical study. Histochemistry 1975;44:281-90.

12 Holst JJ. Enteroglucagon. Annu Rev Physiol 1997;59:25771 .

13 Holst JJ, Orskov C, Nielsen OV, et al. Truncated glucagonike peptide I, an insulin-releasing hormone from the distal gut. FEBS Lett 1987;211:169-74.

14 Mojsov S, Weir GC, Habener JF. Insulinotropin:glucagonlike peptide I (7-37) co-encoded in the glucagon gene is a potent stimulator of insulin release in the perfused rat pancreas. F Clin Invest 1987;79:616-19.

15 Holst JJ. Glucagonlike peptide 1: a newly discovered gastrointestinal hormone. Gastroenterology 1994;107:1848-55.

16 Wojdemann M, Wettergren A, Hartmann B, et al. Glucagonlike peptide-2 inhibits centrally induced antral motility in pigs. Scand F Gastroenterol 1998;33:828-32.

17 Wojdemann M, Wettergren A, Hartmann B, et al. Inhibition of sham feeding-stimulated human gastric acid secretion by glucagon-like peptide-2. f Clin Endocrinol Metab 1999;84: 2513-17.

18 Scott RB, Kirk D, MacNaughton WK, et al. GLP-2 augments the adaptive response to massive intestinal resecaugments the adaptive response to massive in
tion in rat. Am $\mathcal{F}$ Physiol 1998;275:G911-21.

19 Thulesen J, Hartmann B, Kissow H, et al. Intestinal growth adaptation and circulating levels of glucagon-like peptide 2 (GLP-2) following small bowel resection or ileal-jejunal transposition in rats. Dig Dis Sci 2000 (submitted).

20 Jeppesen PB, Hartmann B, Hansen BS, et al. Impaired meal stimulated glucagon-like peptide 2 response in ileal resected short bowel patients with intestinal failure. Gut 1999;45:559-63.

21 Dowling RH. Small bowel adaptation and its regulation. Scand $\mathcal{F}$ Gastroenterol Suppl 1982;74:53-74.

22 Carbonnel F, Cosnes J, Chevret S, et al. The role of anatomic factors in nutritional autonomy after extensive small bowel resection. FPEN $\mathcal{F}$ Parenter Enteral Nutr 1996; 20:275-80.

23 Nightingale JM, Lennard Jones JE, Walker ER, et al. Jejunal efflux in short bowel syndrome (see comments). Lancet 1990;336:765-8.

24 Nightingale JM, Lennard Jones JE, Gertner DJ, et al. Colonic preservation reduces need for parenteral therapy, increases incidence of renal stones, but does not change high prevalence of gall stones in patients with a short bowel. Gut 1992;33:1493-7.

25 Cosnes J, Carbonnel F, Beaugerie L, et al. Functional adaptation after extensive small bowel resection in humans. Eur $\mathcal{f}$ Gastroenterol Hepatol 1994;6:197-202.

26 Nordgaard I, Hansen BS, Mortensen PB. Importance of colonic support for energy absorption as small-bowel failure proceeds. Am f Clin Nutr 1996;64:222-31.

27 Cummings JH, James WP, Wiggins HS. Role of the colon in ileal-resection diarrhoea. Lancet 1973;1:344-7.

28 Schofield WN. Predicting basal metabolic rate, new standards and review of previous work. Hum Nutr Clin Nutr 1985;39(suppl 1):5-41.

29 Jeppesen PB, Staun M, Mortensen PB. Adult patients receiving home parenteral nutrition in Denmark from 1991 to 1996: who will benefit from intestinal transplantation? Scand F Gastroenterol 1998;33:839-46. 
30 Jeppesen PB, Mortensen PB. Intestinal failure defined by measurements of intestinal energy and wet weight absorp:6:701-6.

31 Jeppesen PB, Staun M, Tjellesen L, et al. Effect of intravenous ranitidine and omeprazole on intestinal absorption of water, sodium, and macronutrients in patients with intestinal resection. Gut 1998;43:763-9.

32 Jeppesen PB, Mortensen PB. The influence of a preserved colon on the absorption of medium chain fat in patients with small bowel resection. Gut 1998;43:478-83.

33 Levnedsmiddelstyrelsen (National Food Agency of Denmark), Dankost version 1.3a. Stork $\notin k$ ken centret (The Stork $\notin k k e n$ Center), Herlev, Denmark: Levdedsmiddelstyrelsen, 1989.

34 Hartmann B, Johnsen AH, Ørskov C, Adelhorst K, Thim L, Holst JJ. Structure, measurement and secretion

35 Hvidberg A, Nielsen MT, Hilsted J, et al. Effect of glucagonlike peptide-1 (proglucagon $78-107$ amide) on hepatic glulike peptide-1 (proglucagon 78-107amide) on hepatic glu-
cose production in healthy man. Metabolism 1994;43:1048 .

36 Holst JJ, Bersani M, Johnsen AH, Kofod H, Hartmann B, Orskov C. Proglucagon processing in porcine and human pancreas 7 Biol Chem 1994:269:18827-33.

37 Holst JJ. Evidence that enteroglucagon (II) is identical with the C-terminal sequence (residues 33-69) of glicentin. Biochem f 1982;207:381-8.

38 Xiao Q, Boushey RP, Drucker DJ, et al. Secretion of the intestinotropic hormone glucagon-like peptide 2 is differentially regulated by nutrients in humans (see comments). Gastroenterology 1999;117:99-105.

39 Roberge JN, Brubaker PL. Regulation of intestinal proglucagon-derived peptide secretion by glucosedependent insulinotropic peptide in a novel enteroendocrine loop. Endocrinology 1993;133:233-40.

40 Rocca AS, Brubaker PL. Stereospecific effects of fatty acids on proglucagon-derived peptide secretion in fetal rat intestinal cultures. Endocrinology 1995;136:5593-9.

41 Rocca AS, Brubaker PL. Role of the vagus nerve in mediating proximal nutrient-induced glucagon-like peptide-1 ing proximal nutrient-induced glucagon-

42 Nordgaard I, Mortensen PB, Langkilde AM. Small intestinal malabsorption and colonic fermentation of intestinal malabsorption and colonic fermentation of resistant starch and resistant peptides to short-ch
acids (see comments). Nutrition 1995;11:129-37.

43 Nordgaard I, Hansen BS, Mortensen PB. Colon as a digestive organ in patients with short bowel (see comments) Lancet 1994;343:373-6.

44 Kripke SA, De Paula JA, Berman JM, et al. Experimental short-bowel syndrome: effect of an elemental diet supplemented with short-chain triglycerides. Am 7 Clin Nut 1991;53:954-62.

45 Kripke SA, Fox AD, Berman JM, et al. Stimulation of intestinal mucosal growth with intracolonic infusion of shortchain fatty acids. FPEN $\mathcal{F}$ Parenter Enteral Nutr 1989;13: 109-16.

46 Frankel WL, Zhang W, Singh A, et al. Mediation of the trophic effects of short-chain fatty acids on the rat jejunum trophic effects of short-chain fatty acids on

47 Koruda MJ, Rolandelli RH, Bliss DZ, et al. Parenteral nutrition supplemented with short-chain fatty acids: effect on
the small-bowel mucosa in normal rats. Am 7 Clin Nutr the small-bowel

48 Windmueller HG, Spaeth AE. Identification of ketone bodies and glutamine as the major respiratory fuels in vivo for postabsorptive rat small intestine. F Biol Chem 1978;253 69-76.
49 Sakata T. Stimulatory effect of short-chain fatty acids on epithelial cell proliferation of isolated and denervated jejunal segment of the rat. Scand $\mathcal{F}$ Gastroenterol 1989;24:886-

50 Tappenden KA, Drozdowski LA, Thomson AB, et al. Shortchain fatty acid-supplemented total parenteral nutrition alters intestinal structure, glucose transporter 2 (GLUT2) mRNA and protein, and proglucagon mRNA abundance in normal rats. Am f Clin Nutr 1998;68:118-25

51 Bloom SR, Polak JM. The hormonal pattern of intestinal adaptation. A major role for enteroglucagon. Scand $\mathcal{F}$ Gastroenterol Suppl 1982;14:93-103.

52 Sagor GR, Ghatei MA, Al Mukhtar MY, et al. Evidence for a humoral mechanism after small intestinal resection. Exclusion of gastrin but not enteroglucagon. Gastroenterology 1983;84:902-6.

53 Rountree DB, Ulshen MH, Selub S, et al. Nutrientindependent increases in proglucagon and ornithine decarboxylase messenger RNAs after jejunoileal resection. Gastroenterology 1992;103:462-8.

54 Taylor RG, Verity K, Fuller PJ. Ileal glucagon gene expression: ontogeny and response to massive small bowel expression: ontogeny and response to mas

55 Morin CL, Ling V, Bourassa D. Small intestinal and colonic changes induced by a chemically defined diet. Dig Dis Sci $1980 ; 25: 123-8$

56 Cassidy MM, Lightfoot FG, Grau LE, et al. Effect of chronic intake of dietary fibers on the ultrastructural topography of rat jejunum and colon. a scanning electron microscopy study. Am f Clin Nutr 1981;34:218-28.

57 Sagor GR, Al Mukhtar MY, Ghatei MA, et al. The effect of altered luminal nutrition on cellular proliferation and plasma concentrations of enteroglucagon and gastrin after small bowel resection in the rat. Br F Surg 1982;69:14-18.

58 Goodlad RA, Lenton W, Ghatei MA, et al. Effects of an elemental diet, inert bulk and different types of dietary fibre on the ral diet, inere the rat and relationship to plasma gastrin, enteroglucagon, the rat and relationship to plasma gastrin, enter

59 Jenkins AP, Thompson RP. Enteral nutrition and the small intestine (see comments). Gut 1994:35:1765-9.

60 Izukura M, Evers BM, Parekh D, et al. Neurotensin augments intestinal regeneration after small bowel resection in rats. Ann Surg 1992;215:520-6.

61 Evers BM, Izukura M, Townsend CM, et al. Neurotensin prevents intestinal mucosal hypoplasia in rats fed an elemental diet. Dig Dis Sci 1992;37:426-31.

62 Nightingale JM, Kamm MA, van der Sijp JR, et al. Disturbed gastric emptying in the short bowel syndrome. Evidence for a 'colonic brake'. Gut 1993;34:1171-6.

63 Adrian TE, Ferri GL, Bacarese Hamilton AJ, et al. Human distribution and release of a putative new gut hormone, peptide YY. Gastroenterology 1985;89:1070-7.

64 Nightingale JM, Kamm MA, van der Sijp JR, et al. Gastrointestinal hormones in short bowel syndrome. Peptide YY may be the 'colonic brake' to gastric emptying. Gut 1996;39:267-72.

65 Savage AP, Gornacz GE, Adrian TE, et al. Is raised plasma peptide YY after intestinal resection in the rat responsible for the trophic response? Gut $1985 ; 26: 1353-8$.

66 Messing B, Landais P, Goldfarb B, et al. Home parenteral nutrition in adults: a multicentre survey in Europe. Clin Nutr 1989;8:3-9.

67 Van Gossum A, Bakker H, De Francesco A, et al. Home parenteral nutrition in adults: a multicentre survey in Europe in 1993. Clin Nutr 1996;15:53-9. 